\title{
obituary
}

\section{Dennis Hanson Gath DM (Oxford) FRCP (Lond) FRCPsych}

\section{Formerly Professor Medical Unit, Radcliffe Infirmary, Oxford}

The death on 14 May 2005 of Dennis Gath robs us of one of our foremost social psychiatrists, whose contributions spanned a wide range of subjects, including the relationship between physical and mental illness, a whole range of gynaecological and obstetric disorders, and some excellent original work in primary care. It is largely due to him that women complaining of menorrhagia are today treated for their depression rather than having their uterus removed, and that simple psychological intervention is considered as effective as drugs in the treatment of depression in primary care. Other subjects which concerned him were sterilisation and post-partum depression. His work in community psychiatry included studies of needs for care and homelessness. His many books include an early Maudsley Monograph on juvenile delinquency, books on alcoholism and forensic psychiatry - and, of course, he was an editor of the Oxford Textbook of Psychiatry.

While at Ilford County High School for Boys, Dennis greatly enjoyed acting, and his appearance as Malvolio must have been an inspired piece of casting

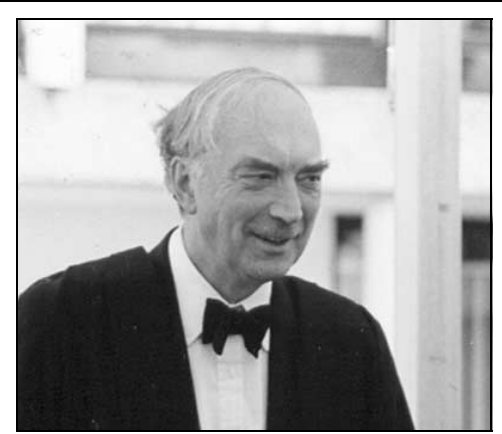

After a brief stint at Birmingham he moved to Oxford as a clinical lecturer. He was soon first assistant to Michael Gelder and eventually Director of the Research Unit in Social and Community Psychiatry, where he produced some of his finest research. During his early years in the Oxford department he was heavily involved in both undergraduate and postgraduate teaching, and had the satisfaction of knowing that several of the consultant psychiatrists in the Oxford region entered the subject because of his teaching to them as medical students. He was a professorial

by his drama teacher as his serious, selfdeprecating manner and his quiet sense of humour fitted well in the role. After school he won an open exhibition to Cambridge to read classics, but changed to psychology and philosophy, and graduated in 1952. He spent a year at the international school in Geneva, where the group of girls he was responsible for were known as 'Mr Gath's Advanced Girls'.

He then went up to Oxford to read medicine, where - owing to the proximity of our surnames - for the next 5 years we went in consecutively to oral examinations, and found light conversation difficult. Our paths crossed again at the Maudsley, and our lifelong friendship took off. We both worked for the late Professor Michael Shepherd, an experience that set Dennis on course for the many major contributions he made to social psychiatry. fellow of Wolfson College, and during my visits appeared to be in great demand by the staff.

Dennis was the only psychiatrist to be included by Richard Smith, then the editor of the $B M J$, in his compilation of doctors of compassion and ability. Photographs were taken and displayed in the National Portrait Gallery, and these appeared in a book called Of Head, and Heart, and Hand. In later years as his research findings became known across the world he gave lectures in many countries, and was especially well known in North America. Dennis was a connoisseur of good food and wine, and an evening spent with him always passed very pleasantly.

His second wife Eileen looked after him during a long and distressing final illness. He is survived by her, and by two daughters and one son from his first marriage.

David Goldberg 